\title{
Entrepreneurial characteristics in SME's A Rural, Remote rural and Urban perspective of Lincolnshire businesses
}

With the global recession cutting ever deeper into market share and profits, it can be said that SMEs are suffering more than most firms when competing in global, national and local markets. The purpose of this article is to examine whether SMEs within remote rural, rural and urban locations differ in their entrepreneurial skills base and if so, does this impact upon their business performance. In this article we examine three key entrepreneurial drivers derived from published research articles and in turn use these as indicators of entrepreneurial activity. The research underpinning this article employs a quantitative format based on a matrix of 100 questions related to entrepreneurial characteristics as defined by contemporary published authors'. The resultant data is used to calculate a composite metric which is termed an entrepreneurial rating. This metric is used to calculate the level of entrepreneurial activity for each of the geographical locations, remote rural, rural and urban. This method and research highlights the importance of entrepreneurial characteristics exhibited by businesses based within a rural county. Such businesses in comparison to other geographical locations throughout the UK may offer contemporary data on similarities in relation to location and business size.

Key words: Entrepreneurship, SMEs, Entrepreneurial characteristics, remote rural, rural, urban, rural county. 
Entrepreneurship is used in many contexts to both describe either an individual or business which may be viewed as exceptional in some way. Evidence would suggest that the term entrepreneurship is often misused and can be frustrating when used to describe business practice and performance where no exceptional abilities or characteristics are evident within the firm. This suggests a number of academic possibilities which are concerned with understanding entrepreneurship and its contextual relationship within rural SMEs. The context of the article is based on entrepreneurship in its collective and theoretical make-up and includes the themes and characteristics of previously published authors who have contributed to the body of knowledge in entrepreneurship.

The term entrepreneurship, in the context of both business and the individual is viewed as synonymous with growth and wealth and also the spotting of opportunities (Timmons, 1989). Bolton and Thompson (2000) try to add value to the term by elaborating that entrepreneurs both 'create and build' and through these endeavours can have a substantive achievement attributed to them. Previous research in relation to the examination of entrepreneurial activity within SME's with the premise of trying to identify fast growing businesses in order to target resources more effectively can be traced back to Storey (1999). Through the identification of such businesses, initiatives have endeavoured to target resources so as to ensure a structured and monitored growth pattern in an attempt to grow such businesses grow thereby not failing through many common problems (Rainer, 2009).

Such a view of the entrepreneur has its foundations firmly set within the early $20^{\text {th }}$ century where the view of the early entrepreneur was more of an intermediary or broker, but more importantly, it displayed the person with a certain and very important characteristic; one who takes risks. This characteristic is viewed by many as an important element of entrepreneurial behaviour which when included in later theories was to play an important role. Kirzner (1973) along with Knight (1921) embrace the work of Cantillon by indicating that the entrepreneur was more a conduit and facilitator or an intermediary of information. Business owners were willing to undertake uncertainty within a market and exploit it, in the certain knowledge they possessed in ensuring a profit could be made, in doing so, coupled with their knowledge, they could lower the uninsurable element of risk as far as possible. This view of the entrepreneur being a risk taker, in conjunction with many academic theories was to play a major part in the debate over what role traits and characteristics should play within entrepreneurial theory (McClelland, 1961). In one sense entrepreneurship may be described as a pure theoretical construct, although it is also implicitly tied to real world research findings.

\section{Review of Literature}

Having a strategic vision can be viewed as an anomaly by some, in that by the adoption of such by any business denotes that they have evaluated every aspect of the business. It is only by the understanding of such fully from the perspective that strategy is an element of entrepreneurial behaviour that the context of such becomes fully understood (Wickham, 2004). By adopting such perceptions, it then opens up a 
plethora of ideas whereby the vision of such can be adapted to the outcomes of the business and the debated areas of entrepreneurial behaviour come into play (Chell, 1985). Such areas need to be considered in that of risk propensity and opportunity recognition and action. This view of the entrepreneur being a risk taker, in conjunction with many related academic theories was deemed to play a major part in the debate over what role traits and characteristics should play within entrepreneurial theory (McClelland, 1961). Previous research in relation to the examination of entrepreneurial activity within SME's with the premise of trying to identify fast growing businesses in order to target resources more effectively can be traced back to Storey (1999). Through the identification of such businesses, initiatives endeavoured to target resources so as to ensure a structured and monitored growth pattern in an attempt to grow such businesses grow thereby not failing through many common problems (Rainer, 2009).

A contrasting view which endeavours to embrace a catholic ethic of entrepreneurship is that of Llewellyn and Wilson (2003) whose debate brings together a plethora of elements, singled out by authors' over many years, in order to give a consensus embrace of the term, they state: "....some people to relate to a set of personal characteristics (especially risk taking, creativity and ambition), a set of behaviours by others (starting a business). Entrepreneurship can be viewed as a pure theoretical construct in one sense, although it is also implicitly tied to real world research findings". They are effectively stating that there is no one definition of an entrepreneur and it is up to researchers to prove their viewpoint through robust and rigorous research.

When reviewing early entrepreneurial theory, it needs to be understood that towards the middle of the eighteenth century, profit maximisation among some business people began to emerge; such behaviour had not been experienced before. Long, (1982) views this as entrepreneurial effort which is a metamorphosed process of what we are experiencing today. It was not until the height of the industrial revolution [1850-1900] that the notion of what is expected of the entrepreneur started to align itself to the term and connotations of it means today. Say (1964; first published in 1803), indicates that the entrepreneur had to be sufficiently multifaceted to be able to control and have coordination of many business areas, these included; the raising of capital, the organisation of production, and also have full command and understanding of the distribution chain. In effect, entrepreneurs were their own managers, building their businesses as they saw fit debating whether they should grow or specialise in niche markets. Today, many rural and remote rural businesses fit this definition, specialising and raising capital to furnish new ideas and processes through innovation. Such businesses seek capital and many through collaboration managed to bring new products and services to market that would have otherwise not have materialised.

It is with such constructs that the role of having an effective innovative strategy, whereby the vision of the business owner and the direction the business takes; are one of the same. Goffee and Scase (1987) state that the function of the entrepreneur can incorporate many abilities and that these may be managed in a way that advocates the advancement of the individual and their ideas which in turn may have an influence upon their vision. This can happen through the management of other 
people or capitalisation of a market sector which in turn demands a certain type and skill. Through the debates of their research it is evident that Goffee and Scase were also aware of the importance of the work by Loasby (1962) and his description of such, as to the supply of "business enterprise" and the factors of helping individuals rise from the working classes. SMEs have been, and are often portrayed as both the lifesavers and driving force of both the community and economy (Hannon, 2005). Such employers, which are often the sole employer within some locations, need public support both in their incubation, infancy and to ride out specific difficulties which in turn would help local communities and reduce the impact of economic change (Rothwell and Zegveld, 1982, Hannon, 2005). Support for such statements has come from many quarters; this includes both central and local government, through which many agencies have been instructed to foster such initiatives. Central Government initiated a scheme called, Encouraging and Supporting Enterprise in Rural Areas (Report to the Small Business Service, 2002). This may go some way to formulating a growth and sustainability strategy for remote and rural areas and the association of encouragement of entrepreneurs to invest and grow their businesses.

By adopting the view that innovation on a micro level is creating competitive advantage by perceiving or discovering new and better ways of competing in an industry and bringing them to market (Porter, 1990). Such views and practices are also advocated by Schumpeter (1934) who broadly outlines that innovation within a tripartite way in encouraged through the technological, political and social aspects of society. It through the recognition of such and the action of acting upon the opportunity that the small business encourages develops the strategic vision. Because the number of firms which are truly innovate within a technological sense are fairly small; the emphasis of innovation within the Schumpeterian perspective is a good one to adopt. It is through such views of what elements need to be included within the strategic vision become apparent and only then can be acted upon and honed to fit both the ideal and vision of the business owner. Gray (2006) states; "If small firms are to fulfil their expected innovative function, it is important to better understand the causes and effects of these knowledge, capabilities and skills gaps in relation to SME growth".

It is clear to see that business owners need to be innovative and learn continuously from social interactions that include many participants (Rosenberg, 1976) these can comprise of customers, consultants and competitors. Change, can also be the catalyst for innovation; it provides the opportunity for systems within a business to be conducted in a different way that may prove more efficient and profitable. If systemic innovation were inherent within an organisation, that organisation would be purposefully looking for change opportunities within all its mode of operations, on a macro and micro environmental basis. The discipline of innovation can also provide entrepreneurial behaviour with opportunities through the identification of change possibilities. These changes can be either of an internal or external exponent, within your field of expertise or at least closely related to it, either within your value chain or forwards or backwards along that chain. Therefore making changes within a value chain framework needs to be closely related to the desires of the business owner in relation to the customer's requirements. This can be said for rural businesses whose association and close relationship with their customers' needs are truly met as they appear to be intrinsically linked through a desired relationship (Bosworth, 2009). 
Innovative behaviour can vary and therefore take many different forms; each of these forms can be attributed to a given situation which again can vary dependent upon a business. Within these variations a number of authors' distinguish between both radical and incremental innovation variations (Dewar and Dutton, 1986). These discussions and debates focus on situations where both radical and incremental innovation can be used. With radical innovation needing a new market for it to "bear fruit" Mensch, (1975), it has been found that such innovation invariably involve a science base, which may include both technology and research and development within its format. This may be due largely to the level of technical knowledge required in their transference from inception to market. Moreover, such cases involve small research led pharmaceutical or telecommunication business whereas having products and patents in late development are bought by larger firms so as to acquire such developments (Utterback, 1993). Incremental innovation can be associated more with SMEs and is more of a production and product development programme that has its roots embedded within the firm. It undoubtedly comes from the workers within the firm who have identified some production, product or process improvement (Hollander, 1965). "Process innovation", can also be linked in a tentative way to incremental innovation, through the development of businessprocess redesign and also by the investment of new capital machinery and technology. The Department of Trade and Industry (2009) has through many schemes promoted the notion of innovative behaviour within business as a building block that needs constant attention; the recent loan guarantee scheme helps businesses with transient costs for innovations in this way businesses can off-set the cost and instigate new methods that would otherwise not happened. As with all innovation, it involves change, these changes could take place within the areas of product, practice technology or market, because innovation is not stable, it adopts the fluidity of market forces, (Mole and Worrall, 2001).

For rural and remote rural businesses such processes involve areas of customer practice and service and through these innovation takes place; whereby they develop such requirements and synchronise these with identified customer needs. This in turn brings about change within the business and continues to evolve in a state of flux, changing as and when the needs arise. Problems arise with urban businesses in that they do not change at the same level or speed as their rural and remote counterparts. It is not because they are not able too, most business can; it is because their owners do not recognise the need for change and through this the failure of such businesses takes place. The rural/remote businesses are more adept at entrepreneurial practices which are directly related to their surroundings and it is through such that they choose to own and operate businesses in such areas. It is as though they are drawn to operate in such surroundings and through this have such affinity with their customer base and needs; which results in them being truly innovative. 


\section{Research Methodology}

The main data gathering tool comprised of a postal survey consisting of 3600 SMEs whose businesses were situated and resident within the county of Lincolnshire. The characterisation of remote rural, rural and urban has been taken from the local authority definition in respect of population. By conducting a large survey it enables a large sample size to be achieved; in the case of this survey a response rate of $13 \%$ was provided through 468 questionnaires, from which 145 were selected due to the detailed level of completion within the questionnaire. From the initial survey, 145 businesses were selected to be included within the analytical stages of the methodology; the reasoning for such a selection process was that only completed and detailed questionnaires could be included collectively providing 100 indices for the formulation of a composite build. Having such a large number of data points enabled cross comparison and analysis of the data sets to take place within key areas of entrepreneurial research and literature.

The overall aim of the design methodology was to drill down both the sample size and data through various stages of analysis, which would result in the compilation of a composite indicator. Such an indicator would be related to three specific areas of test, namely; innovation, opportunity spotting and risk. It is recognised that each of the three areas are well established entrepreneurial characteristics. By adopting such a methodological process enabled both the overall methodology to adopt an organic process; but still remain focused on the main aim of the research; rural entrepreneurship within SMEs in various locations. Through the adoption of and allowing a more organic approach to the research it enabled details to emerge from each of the previous stages of the data collection process, these in turn could be refined and included within the following stages. This added to both to the scope and detail of the overall methodological and research perspective of the survey. To ensure that the survey representative of SMEs within the survey area, a probability sampling technique was employed, the outcome of which ensures that bias and sampling error are kept to a minimum (Bryman and Bell, 2003). The simple random sample is the most basic form of probability sample; it also ensures, within parameters, the sample is representative and that each element has an equal probability of being included within that sample Saunders (2009).

The normalisation and weighting of data, especially when being used within a composite build, needs to be carried in order to level all measurement units. The chosen method conformed to the understanding used by Jacobs et al (2004), in that the yes and no replies were inserted into likert scale at both extremities, that of, 1 and 7 , the no reply became a 3 , and the yes replies a 6 . By implementing such a method it enabled the data to be standardised and aggregated, thus ensuring that a reliable composite being formed. Within the composites are areas viewed by the key authors' as paramount to their view on entrepreneurship -these are the sub-setssome authors' may view these areas as more or less important than their peers. To aggregate these areas a weighting was placed upon them to recognise the importance in relation to the authors' viewpoint. In some cases the sub-set may be assigned to more than one composite, as the sub-set may be included within the overall matrix of opinion on entrepreneurship of that author (Freudenberg, 2003). 
The initial stage of the data collation exercise comprised of inputting the data onto an excel spreadsheet, listing the questions corresponding to the research agenda horizontally, and the businesses vertically. By adopting such an approach it gave the data a corresponding cross referenced alpha-number table consisting from $\mathrm{C} 1$ to BN142, -A and B being the businesses name and address which were not used within and computation processes- along the horizontal/vertical axis. Compiling the data in such a way enabled it to be used easily within the formation of the sub-sets for the prerequisite final composite figure. The second stage of the data analysis consisted of aligning the questions that had been asked of the host businesses within all three stages of the survey process, with key areas of the authors thinking in entrepreneurship.

Composite indicators have increasingly been recognised as a useful tool both within policy analysis and also when advising the public on complex issues. They have also recently been used to compare many different areas of performance within a variety of context, which include business, person or county environments (OECD, EUR, 2005). Composite indicators (C.I's) can and have been used to interpret complex data within an academic context and when used correctly, the reliability of the data is viewed of a higher standard, (OECD, 2005). The construction of C.I.'s involves a number of stages where subjective judgements need to be made: including the selection of sub-indicators, the treatment of missing values, the choice of an aggregation model, the weights of the indicators, etc. Each of these areas can affect the construction of the composite and also the generated result. It must be remembered that there is a need to reflect the phenomenon that is to be measured along, with its sub-components; it should also identify the weights and reflect the importance and overall dimensions of the composite (OECD, 2005).

\section{Findings}

The methodology establishes the rationale for a composite figure for each author, in so far as to the establishing of entrepreneurial characteristics within remote and rural businesses. Although it is but one element of the holistic methodological process, it is an inherent and integral initial part of the data analysis. The composite, by its definition has built within it a number of variables, all derived from an alpha numeric table compiled through questionnaires, so as to ensure a range of characteristics are included within the analysis. Table 1: displays a calculated composite score for each authors' with the results indicating a narrow band width extending from 4.00 (Schumpeter) to 4.73 (Shackle). Such results may be expected when the views of several authors' are used in comparison. What is more interesting, is that the results display the views of the survey sample in that they have a diversity of opinion as to what characteristics they use within daily business activities. In so doing, it also shows the level of accuracy of the research process with the composite scores reflecting the authors' entrepreneurial views, both within the resultant composite score, and also the matrix compilation (Table 2).

Through the table exhibiting such a narrow band, this further reinforces both the research and ideas on entrepreneurial thinking. Although trying to establish differences may be difficult, it is the ideas that businesses within different rural 
settings, offer different nuances and characteristics to those in urban areas, by the known facts that trading in such areas is more difficult. When viewing the author theories within (Table 2) this becomes more apparent in that the theories of Shackle are aligned to that of a perspective which builds upon the many theories of social entrepreneurial behaviour (Cook, et al 2003). This is clear in that Shackle perceives interaction with the local community and in so doing gains valuable knowledge on their needs and requirements. This then leads to entrepreneurial values of the individual to exploit such needs; this is the more traditional view of the entrepreneur. It is the combination of the two that comes out of the data and further explains as to the narrow band width of the composite score given within (Table 1).

TABLE 1

Composite Score for each Author

\begin{tabular}{|l|l|l|l|l|l|}
\hline Schumpeter & Kirzner & Knight & Casson & Shackle & Venkataraman \\
\hline 4.000 & 4.273 & 4.233 & 4.667 & 4.735 & 4.600 \\
\hline
\end{tabular}

In the analysis and accuracy of the two authors' extremities, Schumpeter and Venkataraman; the accuracy of the remaining 4 authors needs to be examined further.

The differentiation between the remaining 4 authors is not as great as the extremes of the initial pair, which is what would be expected. Both Kirzner and Knight score very much the same, 4.27 and 4.23 respectively, again these results reflect a similar viewpoint of the authors' entrepreneurial thinking and research perspective.. Casson and Venkataraman also score very similarly; 4.66 and 4.60 and the same diagnosis that was applied to Kirzner and Knight, also applies to them. The grouping of these two pairs needs to be explored further in relation to the matrix (Table2). It can also be seen that both Casson and Venkataraman do share some similarities within entrepreneurial thinking where overlapping of ideas takes place, but they also have mainstream differing views. Adopting this view to the results leads us to intimate that the difference within the results for all of the authors', although the number may be small; can in fact, represent a large difference within the entrepreneurial areas of each author, this becomes apparent when viewed against the matrix table. It is when this detail is compared to the alpha numeric table it can be seen what question is related to which entrepreneurial ability and how this is attributed within the matrix format. From which a reliable form of analysis can be made in relation to the entrepreneurial traits, nuances and skills business owners use within a remote and rural setting. 
TABLE 2

Author Matrix

\begin{tabular}{|c|c|c|c|c|c|}
\hline Schumpeter & Kirzner & Knight & Casson & Shackle & Venkataraman \\
\hline $\begin{array}{l}\text { Innovator, but } \\
\text { does not see them } \\
\text { as an small } \\
\text { businesses (type } \\
2 \text {, Schumpeter) } \\
\text { Creative } \\
\text { destruction. } \\
\text { Disequilibrium }\end{array}$ & $\begin{array}{l}\text { Ability to spot } \\
\text { profitable } \\
\text { Opportunities for } \\
\text { exchange. Being } \\
\text { alert to all actions } \\
\text { within a market }\end{array}$ & $\begin{array}{l}\text { Risk taker } \\
\text { (dispersion of } \\
\text { possible } \\
\text { alternative future } \\
\text { events) Does } \\
\text { not see risk as } \\
\text { 'normal' risk. } \\
\text { Uninsurable risk }\end{array}$ & $\begin{array}{l}\text { Imaginative, } \\
\text { command over } \\
\text { resources. A } \\
\text { synthesis of other } \\
\text { authors' and } \\
\text { ideas. Milder } \\
\text { innovation }\end{array}$ & Imaginative & $\begin{array}{l}\text { Risk taker (calculated) } \\
\text { The need for } \\
\text { information }\end{array}$ \\
\hline Vision & Intermediary & Confident & Vision & Vision & Vision \\
\hline $\begin{array}{l}\text { Ability to spot new } \\
\text { opportunities out of } \\
\text { old ones }\end{array}$ & $\begin{array}{l}\text { Milder form of } \\
\text { innovation }\end{array}$ & $\begin{array}{l}\text { Predictability/ } \\
\text { opportunity } \\
\text { spotting }\end{array}$ & $\begin{array}{l}\text { Embraces change } \\
\text { to spot } \\
\text { opportunities }\end{array}$ & $\begin{array}{l}\text { Social } \\
\text { behaviour } \\
\text { Trust }\end{array}$ & $\begin{array}{l}\text { Opportunity recognition } \\
\text { and exploitation }\end{array}$ \\
\hline Creative & Creative & Creative & Creative & Creative & Creative \\
\hline $\begin{array}{l}\text { Brings about } \\
\text { change through } \\
\text { the adoption of } \\
\text { new technology }\end{array}$ & $\begin{array}{l}\text { Can disseminate } \\
\text { knowledge and } \\
\text { shoulder the burden } \\
\text { of uncertainty } \\
\text { through confidence } \\
\text { of actions }\end{array}$ & Alert & $\begin{array}{l}\text { Background } \\
\text { wealth/ resources }\end{array}$ & $\begin{array}{l}\text { Background/ } \\
\text { personal } \\
\text { wealth }\end{array}$ & Innovative \\
\hline Conviction & $\begin{array}{l}\text { High need for } \\
\text { information, may } \\
\text { include some } \\
\text { degree of } \\
\text { imagination }\end{array}$ & $\begin{array}{l}\text { Responsible for } \\
\text { ones actions. } \\
\text { Psychological } \\
\text { aspects of the } \\
\text { entrepreneur }\end{array}$ & $\begin{array}{l}\text { Accepts the level } \\
\text { of uninsurable } \\
\text { risk }\end{array}$ & $\begin{array}{l}\text { Able to } \\
\text { recombine/ } \\
\text { exploit } \\
\text { opportunities }\end{array}$ & $\begin{array}{l}\text { Need for autonomy. } \\
\text { High need for } \\
\text { achievement. Risk } \\
\text { propensity. Locus of } \\
\text { control (All linked to } \\
\text { exploiting } \\
\text { opportunities) }\end{array}$ \\
\hline $\begin{array}{l}\text { Able to work with } \\
\text { others }\end{array}$ & Profit & Profit/reward & $\begin{array}{l}\text { Good } \\
\text { disseminator of } \\
\text { information }\end{array}$ & Profit/ reward & $\begin{array}{l}\text { Both individualistic and } \\
\text { group orientated }\end{array}$ \\
\hline $\begin{array}{l}\text { Good disseminator } \\
\text { of information }\end{array}$ & $\begin{array}{l}\text { Acts upon new } \\
\text { technology }\end{array}$ & $\begin{array}{l}\text { Intellectual costs } \\
\text { of information }\end{array}$ & Individualistic & Conviction & Trust \\
\hline $\begin{array}{l}\text { Need for } \\
\text { achievement }\end{array}$ & Individualistic & $\begin{array}{l}\text { Does not trust } \\
\text { employees to } \\
\text { make decisions }\end{array}$ & $\begin{array}{l}\text { Driven. Innovative } \\
\text { in some areas }\end{array}$ & $\begin{array}{l}\text { Confident in } \\
\text { their superior } \\
\text { ability }\end{array}$ & New technology \\
\hline Alert & Conviction & $\begin{array}{l}\text { Work together in } \\
\text { social groups }\end{array}$ & Non trusting & $\begin{array}{l}\text { Good } \\
\text { disseminator }\end{array}$ & $\begin{array}{l}\text { Success driven. Need } \\
\text { for achievement. }\end{array}$ \\
\hline
\end{tabular}

Within Table 3 are the results for each author in relation to geographical location. It can be seen that each author attracts a different score per location; this indicates that businesses within each location are exhibiting slightly different entrepreneurial characteristics per location. Thereby, such businesses are gravitating and acquiring skills in relation to the trading conditions of each location, such a result indicates that entrepreneurs choose a location in relation to their entrepreneurial skills set. In some ways this acts as a filtering of talent whereby businesses owners of equal talent do not end up in direct competition, but operate on the fringe and target a slightly different customer base. Although the results are not conclusive in the acceptance of Shackle, the result does fit with remote rural trading and what the author advocates in that, the more remote the trading conditions the higher the level of skill is what would be expected, due to the harsh trading environment. Thereby, aggressive entrepreneurial characteristics exhibited by business owners ensure their business both survives and performs to their expectations. 
TABLE 3

Spearman's rho Mean Score for Geographical Locations

\begin{tabular}{|c|c|c|c|c|}
\hline Location & Spearman's rho & Opportunity & Innovation & Risk/reward \\
\hline \multirow[t]{6}{*}{ Remote Rural } & Schumpeter & $.377(* *)$ & $.420(* *)$ & $.309(*)$ \\
\hline & Kirzner & $.378(* *)$ & $.361(* *)$ & $.337\left({ }^{* *}\right)$ \\
\hline & Knight & $.409(* *)$ & $.346(* *)$ & $.509(* *)$ \\
\hline & Casson & $.427(* *)$ & $.541(* *)$ & $.403(* *)$ \\
\hline & Shackle & $.529(* *)$ & $.527(* *)$ & $.409(* *)$ \\
\hline & Venkataraman & $.406(* *)$ & $.538\left({ }^{* *}\right)$ & $.455(* *)$ \\
\hline \multirow[t]{6}{*}{ Rural } & Schumpeter & $.296(*)$ & $.394(* *)$ & .264 \\
\hline & Kirzner & $.442(* *)$ & $.461(* *)$ & $.456(* *)$ \\
\hline & Knight & $.534(* *)$ & $.424(* *)$ & $.346(*)$ \\
\hline & Casson & $.605(* *)$ & $.650(* *)$ & $.451(* *)$ \\
\hline & Shackle & $.530(* *)$ & $.584\left({ }^{(* *}\right)$ & $.415(* *)$ \\
\hline & Venkataraman & $.511(* *)$ & $.665(* *)$ & $.475(* *)$ \\
\hline \multirow[t]{6}{*}{ Urban } & Schumpeter & $.556(* *)$ & 289 & .278 \\
\hline & Kirzner & $.504(* *)$ & . 183 & $.369(*)$ \\
\hline & Knight & $.609(* *)$ & .312 & $.339(*)$ \\
\hline & Casson & $.653(* *)$ & $.564\left({ }^{(* *}\right)$ & $.415\left(^{*}\right)$ \\
\hline & Shackle & $.622(* *)$ & $.509(* *)$ & .327 \\
\hline & Venkataraman & $.649(* *)$ & $.466(* *)$ & .331 \\
\hline
\end{tabular}

Within the remote rural location all three areas of test are adopted by different authors', which indicates no specific authors' theory is adopted isolation. By adopting Casson within two locations the sample has indicated that they are imaginative and have command over their resources, are able to spot opportunities and are visionary and have a command over entrepreneurial functionality.

The data also confirms and aligns itself with the debated overviews with the literature, although an anomaly could be considered with the viewpoint of Schumpeter, in that his research states that businesses adopt and embrace a technological perspective, when growing their business. Previous research has indicated that rural businesses are more adept at this type of operation in that they are flexible to change and can adopt new technology. This is true for types of business, mainly small engineering works and manufactures. Other businesses that require an infrastructure such as digital broadband were found within the sample, but such does not equate to the Schumpeterian ethic of new technology. This anomaly can be explained through the level of digital technology available within locations, in so much that some rural locations have greater access to technology than others. This said, it can be argued that Schumpeter's view only applies to the larger business, whereas his earlier view is more in alignment with the small business perspective and in his later works changes to the larger organisation. 
For an acceptance of both the research and applied tests in relation to the overall research methodology an acceptable and reliable method of test needed to be applied. The chosen method which fits within the parameters of the Spearman's rho analysis is that of Kruskal-Wallis test. This test takes the averages of the entrepreneurial abilities displayed by the survey sample, per author, per location to see if any of the locations display any difference within entrepreneurial ability. In the first table (Table 4) the authors' are given a mean rank in relation to the entrepreneurial ability displayed by the sample, per geographical location. The second table (Table 5) gives a significance value of the combined averages of each location, per author, in respect of the entrepreneurial abilities displayed by the sample. This figure needs to be below the acceptable .05 degrees of freedom. By conducting such tests we will be able to establish if each of the areas exhibit different entrepreneurial abilities or are the same in regard to their trading habits.

TABLE 4

Kruskal-Wallis Condition Test

\begin{tabular}{|lrrrrrr|}
\hline \multicolumn{1}{|c}{ Condition } & Schumpeter & $\underline{\text { Kirzner }}$ & $\underline{\text { Knight }}$ & $\underline{\text { Casson }}$ & $\underline{\text { Shackle }}$ & Venkataraman \\
Chi- square & 3.321 & 5.037 & 3.868 & 4.270 & 6.074 & 3.784 \\
df & 2 & 2 & 2 & 2 & 2 & 2 \\
Asymp Sig. & .190 & .081 & .145 & .118 & .048 & .151 \\
\hline
\end{tabular}

TABLE 5

Kruskal-Wallis Test Significance Values of each Location

\begin{tabular}{|c|c|c|}
\hline Author & Location & Mean Rank \\
\hline \multirow[t]{3}{*}{ Schumpeter } & remote rural & 64.59 \\
\hline & rural & 77.75 \\
\hline & urban & 76.81 \\
\hline \multirow[t]{3}{*}{ Kirzner } & remote rural & 62.92 \\
\hline & rural & 77.60 \\
\hline & urban & 79.89 \\
\hline Knight & remote rural & 64.36 \\
\hline
\end{tabular}




\begin{tabular}{|lcc|}
\hline & rural & 75.24 \\
& urban & 80.66 \\
Casson & remote rural & 63.72 \\
& rural & 76.58 \\
Shackle & urban & 79.91 \\
& remote rural & 61.97 \\
& rural & 79.51 \\
Venkataraman & Urban & 78.90 \\
& remote rural & 64.14 \\
& rural & 78.63 \\
& urban & 76.39 \\
\hline
\end{tabular}

The significance values in the above table indicate that Shackle is the only author that displays a value close to the acceptance level of .05. The value at .048 is very close to this level and in this instance it would not be good practice to state that the sample accept the theory of Shackle within all locations. The above tests do therefore indicate that there is no difference between locations within the practice of a single authors' theory on entrepreneurial abilities.

\section{Discussion and Conclusions}

The findings of the analysis give an insight and depth into various and often contentious elements of entrepreneurial behaviour and trading habits of businesses located within a rural county. A review of literature highlighted 100 areas of key entrepreneurial characteristics and traits, the basis of which formed the foundation of a survey methodology disseminated by geographical location. The survey focused on known entrepreneurial characteristics, which are known to be exhibited by successful business owners, trading within a range of geographical locations in order to define if location specific, has any impact upon entrepreneurial activity.

With the findings indicating that Shackle's entrepreneurial view dominated the sample, although not in full acceptance of the Kruskal-Wallis test parameters; such results do suggest that businesses exhibit a level of entrepreneurial ability within their daily and strategic trading activities. The sample of which indicates that there is a mix of new businesses being set up by in-migrants trading alongside long established businesses. Initial indications suggest that the new in-migrant 
businesses exhibit a Shackle approach in entrepreneurial behaviour, but further analysis is needed and will be presented in another article.

An area which needs to be understood is that businesses using these entrepreneurial tools do not view themselves as being entrepreneurial or entrepreneurs; just small business owners. It is this view which is the more interesting, in that such people start, run and grow businesses, not people who are viewed or termed entrepreneurs.

\section{Bibliography}

Bolton, W. K \& Thompson, J, 2000, Entrepreneurs: Talent, Temperament, Technique, (Cited in: The facets of the entrepreneur: identifying entrepreneurial potential. Management Decision, Vol: 42. No: 2 (2004). Elsevier, Butterworth Heinemann, Oxford.

Bosworth, G 2009 Commercial counterurbanisation: an emerging force in rural economic development

Brandstatter, H 1997,Becoming an Entrepreneur- A Question of Personality Structure? Journal of Economic Psychology, Vol: 18, No: 2 April 1997.

Bryman, A \& Bell, E, 2003, Business Research Methods, Oxford University Press.

Burrell, G., \& Morgan, G, 1979. Sociological Paradigms and Organizational analysis, Heinemann, London.

Costa, P.T., \& McCrae, R.R, 1992, Revised NEO Personality Inventory (NEO-PI-R) and NEO Five-Factor Inventory (NEO-FFI) professional manual, Odessa, FL: Psychological Assessment Resource.

Cook, B \& Dodd's, C \& Mitchell, W, Social Entrepreneurship-False Premises and Dangerous Forebodings, Australian Journal of Social Issues. February.

DEFRA, 2011. Statistical Digest of Rural England, HMSO, UK.

Gartner, W, 2001, Is there an Elephant in Entrepreneurship? Blind Assumptions in Theory Development, Journal of Entrepreneurship Theory and Development, Vol: 25.

Goffee, R \& Scase, R, 1987, Entrepreneurship in Europe, Croom Helm, London.

Grant, P \& Perren, L, 2002, Small Business and Entrepreneurial research, International Small Business Journal, Vol: 20 No: 2.

HMSO, 2002, Encouraging and Supporting Enterprise in Rural Areas: Department for Business Enterprise and Regulatory Reform, formerly Small Business Service.

Hannon, $\mathrm{P}, 2005$, Incubation policy and practice: building practitioner and professional capability, Journal of Small Business and Enterprise Development, Vol: 12, No: 1.

Hofstede, G, 1980, Culture Consequences: International Differences in Workrelated Values, Sage Publications, UK

Johnson, B.R, 2001, Toward a multidimensional model of entrepreneurship: the case of achievement motivation and the entrepreneur, Journal of Entrepreneurship Theory and Practice, Spring.

Kirzner, I, 1973,Competition and Entrepreneurship, Chicago, IL, US: University of Chicago Press.

Kline, P, 2000, Handbook of psychological testing, 2nd Ed, Routledge, London. 
Knight, F., 1921, Risk, Uncertainty, and Profit, Augustus Kelly, New York, US.

Llewellyn, D.J \& Wilson, K.M, 2003, The controversial role of personality traits in the entrepreneurial psychology, Education and Training, Vol: 45, No: 6.

Loasby, B. J, 1962, The Entrepreneur in Economic Theory, Blackwell Publishing, London.

Long, J, 1982, The income tax and self employment, National Tax Journal, Vol. 35.

Marshall, A., 1920, Principles of Economics, $8^{\text {th }} \mathrm{Ed}$, Macmillan, London.UK.

McClelland, D.C, 1961, The Achieving Society, Princeton, NJ; Van Nostrand.

OECD, 2005, Organisation for Economic Co-operation and Development, Handbook on Constructing Composite Indicators: Methodology and User Guide, European Union.

Rainer, H., 2009, A multivariate Analysis of the characteristics of rapid growth firms, their leaders and their market, Journal of Small Business and Entrepreneurship. Vol: 22 Issue: 22.pp 429-27.

Rauch, A \& Frese, M, 2000, Psychological approaches to entrepreneurial success: A general model and an overview of findings, In C.L. Cooper \& I.T. Robertson (Eds.), International Review of Industrial and Organisational Psychology, Chichester, Wiley.

Rothwell, R \& Zegveld, W, 1982, Innovation and the Small and Medium Sized Firm, Frances Pinter, London.

Say. J.B., 1964, A Treatises on political Economy, Philadelphia; Lippincott, Grambo \& Co, 1855, trans. C. R. Prinsep, Ed. Clement C. Biddle, $5^{\text {th }}$ edition.

Schmitt-Rodermund, E., 2001, Psychological Predictors of Entrepreneurial Success, [internet], Jena, University of Jena. Available from jena.de/svw/devpsy/projects/download/untern3.pdf [Accessed 24th March 2011].

Shane, S, Kolvereid, L \& Westhead, P., 1991, An exploratory examination of the reasons leading to new firm formation across country and gender, Journal of Business Venturing, November, Elsevier.

Shane, S., 2003, A General Theory of Entrepreneurship, Edward Elgar Publishing, Cheltenham, UK.

Stathopoulos, K, Espenlaub, S, \& Walker, M., 2004, UK executive compensation practices: New economy versus old economy. Journal of Management Accounting Research, Vol: 16 No: 1.

Stevenson, H \& Harmeling, S., 1990, Entrepreneurial Management's Need for a More Chaotic Theory, Journal of Business Venturing, Vol: 5.

Stewart, W.H \& Roth, P.L., 2001, Risk Propensity Differences between Entrepreneurs and Managers: A Meta Analytic Review, Journal of Applied Psychology, 686 No: 1.

Storey, D.J., 1989, Firms Performance and Size: Explanations of the Small Firm Sector, Small Business economics, Vol: 1.

Thomas, A \& Mancino, A., 2007, The relationship between entrepreneurial characteristics, firms positioning and local development, Entrepreneurship and Innovation. Vol: 8, No: 2. pp. 105-114.

Timmons, J.A., 1989. The Entrepreneurial Mind, Andover MA, Brick House publishing

Winter, M \& Rushbrook, L., 2003, Literature Review of the English Rural Economy, Centre for Rural Research School of Geography \& Archaeology University of Exeter 
